\title{
SOCIAL TECHNOLOGY AS A METHOD FOR MANAGEMENT OF THE SOCIAL PROCESSES
}

\author{
Venelin Terziev \\ Academician of the Russian Academy of Natural History, Moscow, Russia, \\ Prof. D.Sc. (Ec.), D.Sc. (National Security), D.Sc. (Social Activities), Ph.D., National Military \\ University, Veliko Tarnovo, Bulgaria; University of Rousse, Rousse, Bulgaria, terziev@skmat.com
}

\begin{abstract}
The article discusses the social technology as a tool for management of the social processes and the methods for assessment of its effectiveness. It makes a review of general assessment analysis on each stage of the program realization- design, implementation and the evaluation of program benefits.
\end{abstract}

Keywords: social technology, social processes, social effectiveness.

\section{INTRODUCTION}

Social technology is a tool for the management of the social processes that provides a framework of consistent actions of an individual, a team and authorities governing a region, an area, a community, city, town or other place of residence. The model of "technologization“ or technological development of the social environment/arrangement/ via the social objects and processes represented in it aggregated by attributes, features, characteristics, methods of forming, manifestation and reproduction. The evaluation of these technologies should take into consideration the effectiveness of the methods used to reach the set goals and the extent to which they ensure the achievement of required results (Georgiev, 2016).

\section{MATERIAL AND METHODS. RESULTS}

The effectiveness of the social technologies could be assessed using valuation analyses that have been widely adopted lately. A valuation analysis could be performed either by the sponsor of the project for design and implementation of a social technology or by the designer of the technology. It is important to note that an assessment review could be performed at the design stage as well as at the implementation stage of the lifecycle of the technology.

The assessment review may focus on the technology end-to-end or only on a part of it. It has to be noted that the assessment review is concentrated on the internal characteristics of the technology, which allows drawing conclusions for its positive and negative qualities. The assessment strategy for the design stage and the implementation stage involve evaluation of the external effects and the program results.

The evaluation of the effectiveness of the technology could be based on different models. The goal 
assessment model is focused on the analysis of the program goals, the extent to which the social technology meets them and the extent to which they are realized. In this case, as a first step, an assessment of the potential goals of a specific social technology and their formulation is performed and, as a second step, the ability of the technological processes to ensure the accomplishment of the goals is reviewed. The effectiveness of a technology is as high as the extent to which it reaches its goals.

The general assessment review is targeted towards discovering the obvious and hidden effects of the social technology. The evaluation of the effectiveness of the social technology is closely related to the complexity of the expected benefits: while there is poly-modality of the real effects for the object, the subject and the social technology itself as a tool, there is no adequate valid document for their measurement.

The effectiveness of the social technologies could be measured via comparison of possible realization levels: the first level could be reached with the existing resources and limitations without implementation of technologies, while the second one is reached via implementation of specific technologies in the context of existing resources and limitations and eventually via development of applied technology tools and elimination of various impediments. In addition, the effectiveness of the social technology is strongly related to the availability of resources for its realization.

The effectiveness of the social technology is determined by subjective, as well as objective factors. The former are related to the individual skills of the experts participating in the implementation of the technology, the level of their professional skills and experience. The objective factors include the factual conditions of the environment, the work processes, the information flow and the control (Georgiev, 2017-a; Terziev, Kanev, 2019)

\section{DISCUSSION}

There have been a number of attempts to describe the methodology for assessment of the effectiveness of social initiatives (social projects and programs). A social initiative implies a specific activity of an organization aiming to change the social status of a community or a category of individuals. A social initiative would include the design of legal, technical and economic conditions for realization of specific goals. A set of social initiatives with common goals is aggregated into the so called social program.

When discussing the programs for social protection of the population executed by the public employment services in Bulgaria, it should be noted that the existing framework for provision of social protection and social services provided is focused on the "process." The social protection authorities, social services and institutions would usually evaluate the effectiveness of their work based on the quantity of service recipients, the volume of provided services and the volume of spent state-budget financial resources or the financial resources attracted from other sources such as operational programs, etc., rather than on the benefits received from the provided services (i.e. how the provided services have affected the behavior, skills and the self-esteem of the targeted population group etc.). Despite the transition to performance management methods, the issues related to the measurement of the benefits of a social program and their comparison to the spent financial resources continue to remain outside the control of the authorities for social protection and financial management.

It is no secret that the lack of sufficient financing for existing and future programs is often underlined to be one of the most acute problems related to the provision of social services. At the same time, in spite of the pressing nature of this problem, it is often omitted that financing is only a resource required to achieve the final outcome - decreasing the pressure in the society, increasing of the welfare, etc.

The insufficient transparency of the budget spend and the strong attention to financial resources could be classified as one of the most crucial factors impacting the effectiveness of political decisions and the ability of the state authorities to improve the quality of social services. Even when social service authorities, the social worker or the employee in the employment agency are well aware of the actual benefits achieved in the provision of social support, the governing bodies would not require and, consequently, would not reward these achievements, but would at best incentivize the processes or at worst - the demonstration of the process. At the same time there are no effective mechanisms for motivation of the service supplier for his/her contribution to accomplish expected results or for his/ her responsibility for achieving them.

One of the accessible instruments that could alleviate this situation and shift the focus onto the benefits obtained from financial resources spent is the assessment of the social programs. The assessment would not only transfer the attention of state authorities to the examination of the achieved results and benefits (both with quantitative and qualitative) but would also improve the analytical skills and knowledge of the social service workers and officers. It provokes the right questions in a timely manner, triggers the application of an analytical approach to decision making regarding budget spend, as well as the development or the 
improvement of the social policy. Does the program achieve its goals? Has the social aid been granted to those intended to receive it? Is there a leakage of financial resources to those, who do not need aid? Are there administrative barriers, hindering the access to common wealth? To what extent do the achieved benefits match spent financial resources? All these and other questions, formulated in the performance of the assessment of the social program, form the group of significant, clear and measurable goals throughout the interim or long-term development of the system for social protection of the population.

The budgets limitations are only one of the external factors determining the need for assessment of the effectiveness of the budget spend. The social pressure coming from the citizens, who are also the potential electors, is another key factor stimulating the implementation of the assessment method. Each social program reflects certain social interests, for example, to have less homeless people, to decrease the number of young people addicted to drugs, to increase the number of elderly people who remain active in the local community, etc. The political pressure from the electors, on one hand, and the budget limits, on the other, determine the necessity to analyze the specific results of a social program, financed by the local budget and to control the purposeful spend of financial resources. The assessment gives the representatives of the local authorities full, meaningful and objective information about the results of the program and the effectiveness of it realization. Thus, the assessment becomes a tool for a feedback loop amongst the authorities, recipients and the program itself. The understanding obtained in the assessment process contributes to the recognition of the program in the local community as well.

The interim assessment aimed at analyzing the outflow of financial resources in the course of the program reveals the reasons for the variance between actual and budgeted spend. In some cases the variance could be due to unrealistic budgets, prepared on the basis of insufficient or inadequate external expenditure drivers. The assessment allows discovering such drivers early in the course of the program and update the expense budget on the basis of more accurate actual data.

The assessment also serves as basis for balanced economical and political rational decisions related to the realization of the program, as well to its timely amendment. Additionally, the assessment allows for a comparison between the social programs and other forms of social aid in cases of budget cuts, when decisions whether to continue the financing should be made.

In the course of a social program new service mechanisms are often used - systems for search and selection of clients, collection methods, models or schedules for rendering a service, etc. A well-performed assessment could discover imperfections in the design of the program or implementation obstacles, thus helping to improve the service mechanism and ultimately to achieve higher effectiveness at lower cost.

In addition, the assessment supports the program management and the experts to gain an overall understanding of the program realization process, including of the tools for achieving the final outcomes. It is important to note that as the results from the assessment help to alter the perception for ineffectiveness of the state governance and control and to create an opportunity to eliminate the barriers between the business and the local authorities.

It is often the case that both the population and the business have a remote idea of what do the local authorities do to increase the wealth fare of the city or region residents. The assessment forces various groups of economic agents, and in particular the business, to consider the effectiveness of the social programs, the possible options for their improvement to meet local population needs and the opportunity to contribute to the solution of local problems.

What are the requirements the assessment is expected to meet? The assessment of the program effectiveness should be based on explicit criteria and reference points expressed in specific indicators. The reference points could include formally accepted standards for social services, but they could also be indicators, developed specifically for the program, for example the minimal quality standards for social services in UK have been developed by the Ministry of Health and authorities such as the Social Services Inspection /SSI/ and the Audit commission /AC/(SSI, 2001-2002) are constantly checking the compliance of provided services with these standards.

The effectiveness of the assessment is dependent on the sponsor of the project. The decision for initiation of the assessment should be taken by manager's superior to (with higher rank) the program management members. Additionally, it is important to ensure the objectivity of the assessment by involving independent experts, whose personal or professional interest is not affected by the results of the assessment. The assessment should be practical and have usable results, which require that it is performed with the participation of on-the-field experts (for example social workers or employees in the social services facing citizens on different topics) and, above all, clients of the program. These two groups of stakeholders are able to provide important information on different aspects of the realization process; emerging obstacles and 
possible solutions for address them (Terziev, 2019a-k; Terziev, 2018-d; Terziev, Georgiev, 2018e-f; Terziev, Arabska, 2014; Terziev, 2015-b; Terziev, Arabska, 2016a).

\section{CONCLUSION}

The reliability of the assessment's results is ensured by assigning experts, who use adequate contemporary methodology tools. The assessment results should be accessible for all main stakeholders and should be subjected to discussions within a broad group of specialists involved in the realization, financing or the design of the social program. One of the main methods used to evaluate the effectiveness of the state programs for social support of the population is the assessment analysis of various indicators measuring the effectiveness on every stage in the lifecycle of the program:

Design stage: the design of the program is assessed using qualitative indicators to measure the main value reference points (compatibility of the goals of the program design with the goals related to the social and economical development of the country, the legal framework and principles and the expectations of the program beneficiaries).

Implementation (realization) stage: the effectiveness of the program is measured using qualitative indicators expressing the organizational, legal and management components (a prerequisite for effective state governance with regards to social issues is the usage of effective mechanism by the state social services engaged in the realization of the program to coordinate the social impact).

Closing (evaluation) stage: the effectiveness of the program is assessed using quantitative indicators for the economical component (comparison of the volume of services and their cost under restricted human and financial resources) as well as qualitative indicators (compatibility of the goals of the program managers with the actual needs of the program beneficiaries) (Terziev, Arabska, 2014; Terziev, 2015-b; Terziev, Arabska, 2016a).

\section{REFERENCE LIST}

Georgiev, Marin. (2016). Obshtestvenoto i ikonomichesko razvitie v konteksta na sotsialnite politiki. // Spisanie za nauka „Novo znanie“. Visshe Uchilishte po Agrobiznes i Razvitie na Regionite, 5, 2016, N 4, str. 26-41, ISSN 2367-4598 (Online), (Print) ISSN 1314-5703 (Георгиев, Марин. Общественото и икономическо развитие в контекста на социалните политики. // Списание за наука „Ново знание“. Висше училище по агробизнес и развитие на регионите, 5, 2016, N 4, стр. 26-41, ISSN 2367-4598 (Online), (Print) ISSN 1314-5703.

Georgiev, Marin. (2017). Sbalansirovannaya karta kak alyternativa malogo biznesa. // Innovatsionnie tehnologii v nauke novogo vrmeni, Sbornik statey Mezhdunarodnoy nauchno - prakticheskoy konferentsii 1 fevralya 2017 g., Ufa NITS AETERNA, Chasty 1, 2017, s. 43-49, ISBN 978-5-00109004-5, ISBN 978-5-00109-007-6 (Георгиев, Марин. Сбалансированная карта как альтернатива малого бизнеса. // Инновационніе технологии в науке нового врмени, Сборник статей Международной научно - практической конференции 1 февраля 2017 г., Уфа НИЦ АЭТЕРНА, Часть 1, 2017, с. 43-49, ISBN 978-5-00109-004-5, ISBN 978-5-00109-007-6).

Georgiev, Marin. (2017a). Impacts of active social programs on labor market. // Mezhdunarodnayy nauchnayy zhurnal "Innovatsionnaya nauka“. NITS Aeterna, N 02-1, 2017, pp. 139-143, ISSN 24106070 (Georgiev, Marin. Impacts of active social programs on labor market. // Международный научный журнал „Инновационная наука“. НИЦ Аэтерна, N 02-1, 2017, pp. 139-143, ISSN 24106070).

Terziev, V., Kanev, D. (2019). Modern developments in behavioral economics. // Smart Technologies and Innovations in Design for Control of Technological Processes and Objects: Economy and Production Proceeding of the International Science and Technology Conference „FarEastCon-2018” Volume 138, October 2-4, 2018, Vladivostok, Russian Federation, pp. 10-23, 2019, (Print) ISBN978-3-030-15576-6, (Online) ISBN978-3-030-15577-3.

Terziev, Venelin. (2019a). Provision of integrated employment and social assistance services in Bulgaria. // Smart Technologies and Innovations in Design for Control of Technological Processes and Objects: Economy and Production Proceeding of the International Science and Technology Conference „FarEastCon-2018” Volume 138, October 2-4, 2018, Vladivostok, Russian Federation, pp. 24-39, 2019, (Print) ISBN978-3-030-15576-6, (Online) ISBN978-3-030-15577-3. 
IJASOS- International E-Journal of Advances in Social Sciences, Vol. V, Issue 14, August 2019

Terziev, Venelin. (2019b). Problems of control in the social sphere. // INTCESS 2019- $6^{\text {th }}$ International Conference on Education and Social Sciences, 4-6 February, 2019, Dubai, International Organization Center of Academic Research, Istanbul, Turkey, pp. 577-593, ISBN: 978-605-82433-5-4.

Terziev, Venelin. (2019c). The criterion "competence" in the economic sector. // INTCESS 2019- $6^{\text {th }}$ International Conference on Education and Social Sciences, 4-6 February, 2019, Dubai, International Organization Center of Academic Research, Istanbul, Turkey, pp. 1241-1247, ISBN: 978-605-824335-4.

Terziev, Venelin. (2019d). Social policy and labor market development in Bulgarian transition period. // INTCESS 2019- $6^{\text {th }}$ International Conference on Education and Social Sciences, 4-6 February, 2019, Dubai, International Organization Center of Academic Research, Istanbul, Turkey, pp. 703-714, ISBN: 978-605-82433-5-4.

Terziev, Venelin. (2019e). Theoretical basis of development of labor market and social policy in the republic of Bulgaria. // INTCESS 2019- ${ }^{\text {th }}$ International Conference on Education and Social Sciences, 4-6 February, 2019, Dubai, International Organization Center of Academic Research, Istanbul, Turkey, pp. 715-726, ISBN: 978-605-82433-5-4.

Terziev, Venelin. (2019f). The problem of social efficiency- Indicators for social efficiency. // INTCESS 2019$6^{\text {th }}$ International Conference on Education and Social Sciences, 4-6 February, 2019, Dubai, International Organization Center of Academic Research, Istanbul, Turkey, pp. 669-678, ISBN: 978605-82433-5-4.

Terziev, Venelin. (2019g). Experiencing social policy development and efficiency measurment. // INTCESS 2019- $6^{\text {th }}$ International Conference on Education and Social Sciences, 4-6 February, 2019, Dubai, International Organization Center of Academic Research, Istanbul, Turkey, pp. 679-686, ISBN: 978605-82433-5-4.

Terziev, Venelin. (2019h). Efficiency and assessment of social technology. // INTCESS 2019- $6^{\text {th }}$ International Conference on Education and Social Sciences, 4-6 February, 2019, Dubai, International Organization Center of Academic Research, Istanbul, Turkey, pp. 687-694, ISBN: 978-605-82433-5-4.

Terziev, Venelin. (2019i). Conceptual framework of social adaptation. // INTCESS 2019- 6th International Conference on Education and Social Sciences, 4-6 February, 2019, Dubai, International Organization Center of Academic Research, Istanbul, Turkey, pp. 494-503, ISBN: 978-605-82433-5-4.

Terziev, Venelin. (2019j). The dependence social adaptation- socialization. // INTCESS 2019- th $^{\text {th }}$ International Conference on Education and Social Sciences, 4-6 February, 2019, Dubai, International Organization Center of Academic Research, Istanbul, Turkey, pp. 478-485, ISBN: 978-605-82433-5-4.

Terziev, Venelin. (2019k). Social activity and human resources as social development factors. // INTCESS 2019- $6^{\text {th }}$ International Conference on Education and Social Sciences, 4-6 February, 2019, Dubai, International Organization Center of Academic Research, Istanbul, Turkey, pp. 546-553, ISBN: 978605-82433-5-4.

Terziev, Venelin. (2018). The active model of a social programme and its strategic advantage .// ADVED 2018- 4th International Conference on Advances in Education and Social Sciences Abstracts \& Proceedings, 15-17 October 2018- Istanbul, Turkey, International Organization Center of Academic Research, www.ocerints.org, Istanbul, Turkey, 2018, pp. 189-203, ISBN: 978-605-82433-4-7.

Terziev, Venelin. (2018a). Active social programs development in Bulgaria: contemporary challenges and social management instruments. // ADVED 2018- $4^{\text {th }}$ International Conference on Advances in Education and Social Sciences Abstracts \& Proceedings, 15-17 October 2018- Istanbul, Turkey, International Organization Center of Academic Research, www.ocerints.org, Istanbul, Turkey, 2018, pp. 149-163, ISBN: 978-605-82433-4-7.

Terziev, Venelin. (2018b). Social assistance services and integrated employment in Bulgaria. // ADVED 2018- $4^{\text {th }}$ International Conference on Advances in Education and Social Sciences Abstracts \& Proceedings, 15-17 October 2018- Istanbul, Turkey, International Organization Center of Academic Research, www.ocerints.org, Istanbul, Turkey, 2018, pp. 164-177, ISBN: 978-605-82433-4-7.

Terziev, Venelin. (2018c). Impact of the labor market policies for ensuring employment. // ADVED 2018- $4^{\text {th }}$ International Conference on Advances in Education and Social Sciences Abstracts \& Proceedings, 1517 October 2018- Istanbul, Turkey, International Organization Center of Academic Research, www.ocerints.org, Istanbul, Turkey, 2018, pp. 178-188, ISBN: 978-605-82433-4-7. 
Terziev, Venelin. (2018d). Importance of human resources to social development. // ADVED 2018- $4^{\text {th }}$ International Conference on Advances in Education and Social Sciences Abstracts \& Proceedings, 1517 October 2018- Istanbul, Turkey, International Organization Center of Academic Research, www.ocerints.org, Istanbul, Turkey, 2018, pp. 204-212, ISBN: 978-605-82433-4-7.

Terziev, V., Georgiev, M. (2018e). A strategic framework for the development of social entrepreneurship in Bulgaria. // Knowledge - International Journal, August 2018, Institute of Knowledge Management, Skopje, Macedonia, 25, 2018, N 1, pp. 23-34, ISSN 1857-923X (for e-version), ISSN 2545 - 4439 (for printed version).

Terziev, V., Georgiev, M. (2018f). Support for the development of social entrepreneurship in Bulgaria. // Knowledge - International Journal, September, 2018, Institute of Knowledge Management, Skopje, Macedonia, 26, 2018, N1, pp.57-74, ISSN 1857-923X (for e-version), ISSN 2545 - 4439 (for printed version).

Terziev, V., E., Arabska. (2014). Assessment of active social policies' impacts on labor market in the Republic of Bulgaria. Kolektivnaya monografiya "Sotsialyno-ekonomicheskie i pravovay razvitiya ekonomiki“, Ufa, Aeterna. Rossiya, 2014. ISBN 978-5-906769-97-8, str. 3-57 (Terziev, V., E. Arabska. (2014). Assessment of active social policies' impacts on labor market in the Republic of Bulgaria. Колективная монография „Социально-экономические и правовы развития экономики“, Уфа, Аэтерна. Россия, 2014. ISBN 978-5-906769-97-8, стр. 3-57).

Terziev, Venelin. (2015). Impact of active social policies and programs in the period of active economic transformations in Bulgaria, „East West” Association for Advanced Studies and Higher Education, Vienna, 2015, ISBN 78-3-903063-44-0, 434 p.

Terziev, Venelin. (2015a). Assessment of active social policies impact of social policies on transformation processes in bulgarian economy, Moscow, 2015, Publisher „Перо“, 110 p.

Terziev, Venelin. (2015b). Opportunities for improving the efficiency of the social adaptation of servicemen discharged from military service in Bulgaria:- Novosibirsk: Publisher CRNS, 2015. ISBN 978-5-00068402-3, 270 p.

Terziev, V., E., Arabska. (2016a). Effektivnoe vliyanie na raynok truda posredstvom uluchsheniya realizatsii sotsialynoy politiki. Novosibirsk: Izdatelystvo TSRNS, 2016. ISBN 978-5-00068-496-2, 312 str (Терзиев, В., Е. Арабска. (2016а). Эфрфективное влияние на рынок труда посредством улучшения реализации социальной политики. Новосибирск: Издательство ЦРНС, 2016. ISBN 978-5-00068-496-2, 312 стр). 